\title{
PROCESS OPTIMIZATION FOR PECTINASE PRODUCTION BY LOCALLY ISOLATED FUNGAL STRAIN USING SUBMERGED FERMENTATION
}

\author{
OTIMIZAÇÃO DE PROCESSOS PARA PRODUÇÃO DE PECTINASE POR CEPA \\ FÚNGICA LOCALMENTE ISOLADA USANDO FERMENTAÇÃO SUBMERSA
}

\author{
Roheena ABDULLAH ${ }^{1}$; Amna JAFER ${ }^{1}$; Kinza NISAR ${ }^{1}$; Afshan KALEEM ${ }^{\mathbf{1}}$; \\ Mehwish IQTEDAR ${ }^{1}$; Tehreema IFTIKHAR ${ }^{2}$; Faiza SALEEM $^{1}$; Shagufta NAZ $^{1}$ \\ 1. Department of Biotechnology Lahore College for Women University, Lahore, Pakistan. \\ roheena_abdullah@yahoo.com;2. Department of Botany Lahore College for Women University, Lahore, Pakistan
}

\begin{abstract}
The present study deals with the isolation screening and optimization of fungal strain for pectinase production. The fungal strains were isolated from different sources, including soil, fruits etc. Qualitative screening was performed on the basis of the pectin hydrolysis zone. While, quantitative screening was carried out employing submerged fermentation. Among all the strains the strains showing highest pectinolytic potential were selected identified and assigned the code Aspergillus niger ABT-5.The influence of different fermentation media on pectinase production was evaluated. The M5 medium containing $10 \mathrm{~g}$ wheat bran, nutrient medium containing $\left.(\mathrm{g} / \mathrm{l}) \mathrm{of}_{(\mathrm{NH}}\right)_{2} \mathrm{SO}_{4}$ $6.0, \mathrm{~K}_{2} \mathrm{HPO}_{4} 6.0, \mathrm{KH}_{2} \mathrm{PO}_{4} 6.0, \mathrm{MgSO}_{4} .7 \mathrm{H}_{2} \mathrm{O} 0.1$ gave the highest pectinase production. The other important physico chemical parameters including incubation period, temperature, and volume of media, size of inoculum, carbon and nitrogen sources were also optimized for pectinase production. The highest pectinase production $(15.5 \mathrm{U} / \mathrm{ml}) \mathrm{was}$ obtained at $72 \mathrm{~h}$ of incubation, $\mathrm{pH} 6$, temperature $30^{\circ} \mathrm{C}$, volume of media $50 \mathrm{ml}$. Fructose and urea were designated as best carbon and nitrogen sources subsequently.
\end{abstract}

KEYWORDS: Pectinase. Aspergillus niger. Submerged fermentation. Wheat bran.

\section{INTRODUCTION}

Pectinase (E.C.3.2.1.15) represents a complex enzymatic system which hydrolyses the glycosidic linkage present in pectic substances resulting in the formation of monogalacturonic acid (PINHEIRO et al., 2017). Pectic substances are the high molecular weight glycosidic macromolecule contained a backbone of $\alpha-1$, 4-linked D galacturonic acid residues which consist of carboxyl group at C-6. The carboxyl group is esterified with methyl group that is present in some residues (REID; RICARD, 2000). The utilization of pectinase has found broad technological application in different industrial processes. Pectinase are immensely used in food and drink industry, mostly in the fruit juice clarification process because during the process of clarification they are effective for minimizing the thickness of liquors. In addition, they also have other application, including curing of cocoa beans and coffee, extraction of vegetable oils, vegetable fibers clarification and yield starch free pectin In fact pectinase are often used in the treatment of natural fibers such as ramie and cotton fibers in the textile industry as well as bio pulping of papers (BENNAMOUN et al., 2016).

Different sources like plants, fungi and bacteria can be used for the production of pectinases. However, pectinase production from microorganism is preferred over plants because the plant produces potentially harmful material including phenolic compounds and endogenous enzyme inhibitor, difficult to isolate and limited quantity of enzyme is produced (MOREIRA et al., 2005). In addition to this microorganism are also preferable due to low cost production, able to manipulate genetically, the presence of great diversity in chemical and physical characteristic and culture development is fast independent from seasonal fluctuations. Fungi have given preference over bacteria for the production of pectinase because of their ability to colonize the substrate by the apical growth penetration as compared to bacteria. Fungi produce large quantities of enzyme by utilizing the low cost substrate (ANITHA; PALANIVELU, 2013). A large number of fungal genera are used for pectinase production. The most commonly used genera among them include Aspergillus, Rhizopus Trichoderma, Penicillium and Fusarium (AHMED et al., 2016).

Both submerged and solid state fermentation has been used for the pectinase production. However, submerged fermentation considered to be more advantageous as compared to solid state fermentation due to ease of process control and sterilization, require less labour and space, low risk of infection, automation is easier, less contamination and product yield are usually 
higher as compared to input cost (MATHEW et al., 2016). Optimization of different physico chemical parameters includes incubation period, temperature, $\mathrm{pH}$, carbon as well as nitrogen sources for selected fungal strain is a key step for the enhanced production of pectinase (NEETA et al., 2011).

\section{MATERIAL AND METHODS}

\section{Isolation and screening of fungi}

Twenty five different fungal strains were isolated from different sources, i.e. soil and fruits according to Adeleke et al.(2012). One gram of all samples was mixed in $100 \mathrm{ml}$ of sterilized distilled water. Several dilutions were made ranging from $10^{4}$ to $10^{7}$.Then poured $0.1 \mathrm{ml}$ of each dilution on the petri plate containing pectinase screening agar medium(PSAM) and spread uniformly. All the plates were incubated at $30^{\circ} \mathrm{C}$ for 3 to 4 days for the growth of fungi. The colonies showing bigger zones of pectin hydrolysis were selected and identified on the basis of micro and macroscopic features (THANGARATHAM ; MANIMEGALAI, 2014). In order to clearly observe zone of pectin hydrolysis petriplates containing the fungal colonies were flooded with iodine solution for $15 \mathrm{~min}$.

\section{Preparation of conidial/spore inoculum}

The spore or conidial inoculum was prepared by adding $10 \mathrm{ml}$ of sterilized saline water in 4 days old slant having plentiful fungal growth. The spores were dispersed in saline water by carefully scratching with a sterile inoculation loop and vigorously shaking the test tubes for the preparation of homogenized suspension.

\section{Submerged fermentation}

$25 \mathrm{ml}$ of the sterilized fermentation medium was inoculated with $1 \mathrm{ml}$ of inoculum and kept at $30^{\circ} \mathrm{C}$ for 72 hours in shaking incubator at $160 \mathrm{rpm}$. After a fixed period of time fermented broth was centrifuged for $15-20 \mathrm{~min}$ at $6000 \mathrm{rpm}$. The clear supernatant was used for the determination of pectinase activity. All the experiments were performed in triplicates (AHMED et al., 2016).

\section{Fermentation media}

Several different media $(\mathrm{g} / \mathrm{l})$ were screened for the pectinase production.

M1: $50 \mathrm{ml}$ of medium containing $(\mathrm{g} / \mathrm{l}) \mathrm{KH}_{2} \mathrm{PO}_{4}$ 4; $\mathrm{Na}_{2} \mathrm{HPO}_{4} \quad 2 ; \quad \mathrm{FeSO}_{4} . \quad 7 \mathrm{H}_{2} \mathrm{O} \quad 0.2 ; \mathrm{CaCl}_{2} \quad 0.01$; $\left(\mathrm{NH}_{4}\right)_{2} \mathrm{SO}_{4} 2 ; \mathrm{MnSO}_{4} .7 \mathrm{H}_{2} \mathrm{O} 0.007 ; \mathrm{H}_{3} \mathrm{BO}_{3} 0.01$ and pectin 15 (MALDONADO; STRASSER DE SAAD, 1998).
M2: $10 \mathrm{~g}$ banana peel, $50 \mathrm{ml}$ of medium containing (g/l) of $1.4\left(\mathrm{NH}_{4}\right)_{2} \mathrm{SO}_{4} ; 6 \mathrm{~K}_{2} \mathrm{HPO}_{4} ; 2 \mathrm{KH}_{2} \mathrm{PO}_{4}$; and $0.1 \mathrm{MgSO}_{4} .7 \mathrm{H}_{2} \mathrm{O}$ (SOARES et al., 1999).

M3: $50 \mathrm{ml}$ nutrient medium containing $(\mathrm{g} / \mathrm{l})$ of $\mathrm{K}_{2} \mathrm{HPO}_{4} \cdot 3 \mathrm{H}_{2} \mathrm{O} 1$; yeast extract 5; sucrose 30 and Czapek concentrate 10. Czapek concentrate contained $(\mathrm{g} / 100 \mathrm{ml})$ of $\mathrm{NaNO}_{3} 30, \mathrm{KCl} 5$, $\begin{array}{llll}\mathrm{MgSO}_{4} .7 \mathrm{H}_{2} \mathrm{O} & 5, & \mathrm{FeSO}_{4} .7 \mathrm{H}_{2} \mathrm{O} & 0.1\end{array}$ (PALANIYAPPAN et al., 2009).

M4: $2 \mathrm{~g}$ pectin $50 \mathrm{ml}$ Czepak concentrate containing $(\mathrm{g} / 100 \mathrm{ml})$ of $\mathrm{NaNO}_{3} 30, \mathrm{KCl} 5, \mathrm{MgSO}_{4} \cdot 7 \mathrm{H}_{2} \mathrm{O} 5$, $\mathrm{FeSO}_{4} .7 \mathrm{H}_{2} \mathrm{O}$ 0.1g (HANNAN et al., 2009).

M5 : $10 \mathrm{~g}$ wheat bran , nutrient medium containing (g/l) of $\left(\mathrm{NH}_{4}\right)_{2} \mathrm{SO}_{4} 6.0, \mathrm{~K}_{2} \mathrm{HPO}_{4} 6.0, \mathrm{KH}_{2} \mathrm{PO}_{4} 6.0$ and $\mathrm{MgSO}_{4} .7 \mathrm{H}_{2} \mathrm{O} 0.1$ (OKAFOR et al., 2010).

M6: rice bran $10 \mathrm{~g}, 50 \mathrm{ml}$ nutrient medium containing $(\mathrm{g} / \mathrm{l})$ of $\left(\mathrm{NH}_{4}\right)_{2} \mathrm{SO}_{4}$ 6.0, $\mathrm{K}_{2} \mathrm{HPO}_{4}$ 6.0, $\mathrm{KH}_{2} \mathrm{PO}_{4} 6.0$ and $\mathrm{MgSO}_{4} .7 \mathrm{H}_{2} \mathrm{O} 0.1$ (KUNTE ; SHASTRI, 1980).

\section{Enzyme assay}

Pectinase activity was determined using substrate (citrus pectin) following the method Okafor et al. (2010) The reaction mixture contained $1 \mathrm{ml}$ pectin $(1 \%)$ prepared in sodium acetate buffer $(0.1 \mathrm{M} ; \mathrm{pH} 5.5)$ and $1 \mathrm{ml}$ crude enzyme was incubated at $50^{\circ} \mathrm{C}$ in water bath for 30 minutes. After incubation $1 \mathrm{ml}$ of DNS reagent was added and kept for $5 \mathrm{~min}$ in boiling water bath followed by adding $7 \mathrm{ml}$ of distilled water. A blank was also run parallel in which one $\mathrm{ml}$ of distilled water was added instead of enzyme extract. The reducing sugars were determined according to MILLER (1959) method. The absorbance was recorded at $540 \mathrm{~nm}$ using spectrophotometer. The galacturonic acid was used as a standard.

One unit (U) of enzyme activity was defined as the“ amount of enzyme that required to release one micromole of galacturonic acid under the standard assay conditions" (MINJARES-CARRANCO et al., 1997).

\section{Total protein estimation}

Total protein was determined according to the BRADFORD method (1976)

\section{Statistical analysis}

All the data were subjected to statistical analysis. The statistical analysis was carried out applying the one way ANOVA and mean value were compared using Duncun multiple range test. The significance was represented at the level of $p \leq$ 0.05 using SPSS version 21. 


\section{RESULTS AND DISCUSSION}

The isolation and screening of suitable fungal strain is essential for the economic and successful production of pectinase. For this purpose different fungal strains were isolated from different sources (i.e. Soil, decaying fruits and vegetables) by serial dilution method (ADELEKE et al., 2012). The primary screening of pectinase producing strains were carried out using PSAM plates. All the fungal strains showing bigger zone of pectin hydrolysis were selected and subjected to secondary screening through submerged fermentation (Table1). Among all the tested isolates the fungal strain exhibited highest pectinase potential was identified and assigned the code Aspergillus niger ABT-5 (THANGARATHAM; MANIMEGALAI, 2014).

Table 1. Screening of pectinase producing fungi

\begin{tabular}{|c|c|c|c|}
\hline Sr.no & Isolates & $\begin{array}{c}\text { Enzyme activity } \\
(\mathbf{U} / \mathbf{m l})\end{array}$ & $\begin{array}{c}\text { Total protein } \\
(\mathrm{mg} / \mathrm{ml})\end{array}$ \\
\hline 1 & A. fumigatus & $3.64 \pm 0.03$ & $0.21 \pm 0.03$ \\
\hline 2 & A.tamarrii & $4.20 \pm 0.05$ & $0.27 \pm 0.01$ \\
\hline 3 & A. terraus & $4.30 \pm 0.05$ & $0.29 \pm 0.05$ \\
\hline 4 & Rhizopus sp & $3.70 \pm 0.05$ & $0.23 \pm 0.01$ \\
\hline 5 & A.niger & $6.00 \pm 0.50$ & $0.43 \pm 0.02$ \\
\hline 6 & Penicillium sp & $2.32 \pm 0.25$ & $0.15 \pm 0.02$ \\
\hline 7 & A.oryzae & $3.31 \pm 0.25$ & $3.11 \pm 0.02$ \\
\hline 8 & A.niger & $4.01 \pm 0.05$ & $0.25 \pm 0.02$ \\
\hline 9 & A.oryzae & $3.31 \pm 0.25$ & $0.30 \pm 0.02$ \\
\hline 10 & A. fumigatus & $2.53 \pm 0.20$ & $0.12 \pm 0.025$ \\
\hline 11 & Rhizopus sp & $1.41 \pm 0.20$ & $0.09 \pm 0.026$ \\
\hline 12 & Rhizopus sp & $1.11 \pm 0.20$ & $0.08 \pm 0.04$ \\
\hline 13 & Penicillium sp & $0.89 \pm 0.026$ & $0.07 \pm 0.025$ \\
\hline 14 & Penicillium sp & $0.46 \pm 0.30$ & $0.10 \pm 0.01$ \\
\hline 15 & A.oryzae & $3.04 \pm 0.03$ & $0.30 \pm 0.05$ \\
\hline 16 & A.niger & $2.94 \pm 0.02$ & $0.15 \pm 0.02$ \\
\hline 17 & A.tamarrii & $0.46 \pm 0.30$ & $0.10 \pm 0.01$ \\
\hline 18 & Rhizopus sp & $1.21 \pm 0.30$ & $0.07 \pm 0.03$ \\
\hline 19 & A.niger & $1.51 \pm 0.20$ & $0.1 \pm 0.026$ \\
\hline 20 & A.oryzae & $0.56 \pm 0.30$ & $0.10 \pm 0.01$ \\
\hline 21 & Penicillium sp & $2.46 \pm 0.30$ & $0.20 \pm 0.1$ \\
\hline 22 & A.niger & $3.90 \pm 0.05$ & $0.25 \pm 0.03$ \\
\hline 23 & A.oryzae & $3.31 \pm 0.25$ & $3.11 \pm 0.02$ \\
\hline 24 & Rhizopus sp & $2.52 \pm 0.25$ & $0.20 \pm 0.02$ \\
\hline 25 & A. fumigatus & $3.10 \pm 0.05$ & $0.24 \pm 0.02$ \\
\hline
\end{tabular}

Every value is mean of triplicates \pm indicates the standard deviation between replicates.

The selection of appropriate fermentation media is very important for the high yield of enzyme because it provides the nutrient and energy for the growth of microorganism. In the current research six different fermentation media were screened for pectinase production (Fig1). The M5 media gave maximal pectinase productivity $(8.0 \mathrm{U} / \mathrm{ml})$ and total protein $0.56 \mathrm{mg} / \mathrm{ml}$. The reason might be that the components of M5 medium facilitate better growth of fungi. The presence of wheat bran provide adequate amount of nutrients that stimulate better microbial growth, which in turn produced the maximum amount of enzyme (BALKAN; ERTAN, 2007). 


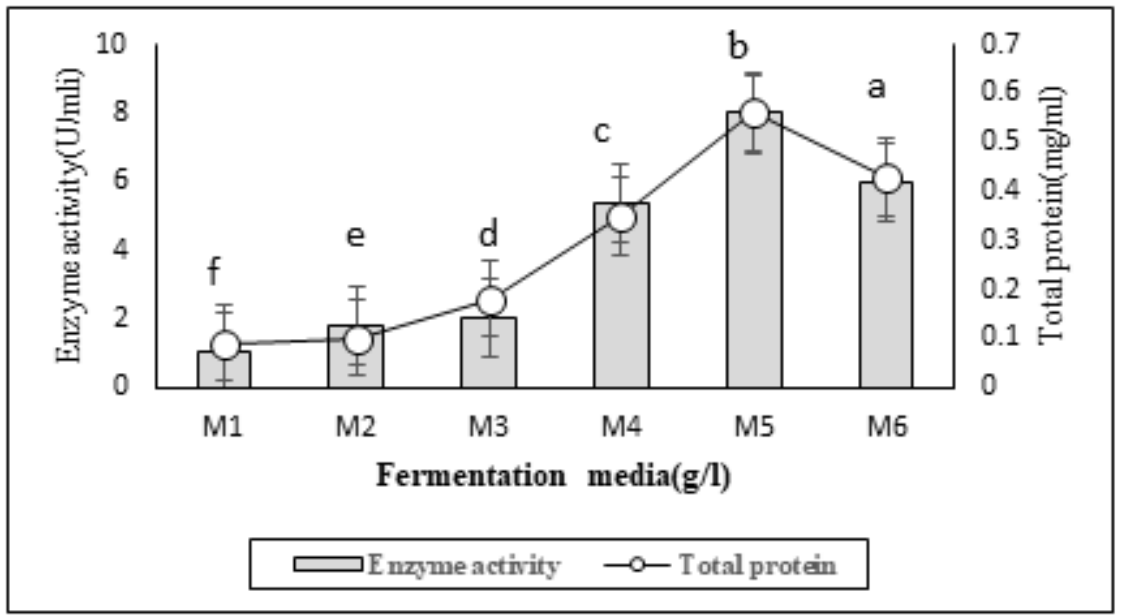

Figure 1. Impact of different fermentation media

Each value is mean of triplicates. Error tindicates the standard error from mean value. Duncan multiple range test shows that mean difference is significant at level of $p \leq 0.05$ represented by different superscripts

The time of incubation plays a critical role in the fermentation process. The period of fermentation depends upon the type of microorganism, composition of medium used and other physiological conditions. In order to find out the influence of incubation period; pecinase production by A.niger ABT-5 was reordered from 0 $120 \mathrm{~h}$ (Fig2 a). The estimation of pectinase was performed after every 24 hours. It was found optimal production $(8.0 \mathrm{U} / \mathrm{ml})$ was obtained at $72 \mathrm{~h}$. The total protein was $(0.56 \pm 0.01 \mathrm{mg} / \mathrm{ml})$. The enzyme production decreases with further increase in incubation time. The reduction in enzyme production might be due to exhaustion of nutrient and metabolite accumulation in the medium (PALANIYAPPAN et al., 2009). Our findings are in contrast to SETHI et al. (2015) who reported 96hours are optimal time period for the production of pectinase. The shorter fermentation period is more beneficial and increases the industrial importance of strain. So our findings are more appreciable than the previously reported.

The incubation temperature is another important factor that greatly affects fungal growth and production of enzymes. In the current study the enzyme production at different temperatures $\left(20^{\circ} \mathrm{C}\right.$ $50^{\circ} \mathrm{C}$ ) was recorded, but the maximum enzyme was produced at $30^{\circ} \mathrm{C}$ (Fig $2 \mathrm{~b}$ ). It was found that the production of pectinase was very low at $50^{\circ} \mathrm{C}$. Perhaps it was due the reason that denaturation of enzymes was occurred at higher temperature (THANGARATHAM; MANIMEGALAI, 2014). At lower temperature there is slow growth of fungi resulted less enzyme production (BAILEY; PESSA, 1990).

The optimization of medium volume is essential for enhanced production of enzymes. In the present study different volume of medium $(25 \mathrm{ml}-$ $150 \mathrm{ml})$ was assessed. The optimal pectinase production was recorded in $50 \mathrm{ml}$ of medium (Fig $2 \mathrm{c})$. When the volume of the media increases above the optimal level the reduction in pectinase production was observed. The reason could be that increase volume of media reduces the oxygen supply, decreased agitation and recirculation of media components resulted the less nutrient availability to the organism; which leading to less growth and lower enzyme production (HAQ et al., 2008). Size of inoculum is another essential factor for the pectinase production. Different size of inoculum ranges from $1-3 \mathrm{ml}$ was optimized for pectinase production. (Fig 2d) In the current study the $1 \mathrm{ml}$ inoculum size produced maximum enzyme in contrast to other sizes. The reason might be the higher inoculum size causes over accumulation of spores and competition for the nutrient among the fungal cells resulted less growth and less enzyme production. While, low inoculum density may not be adequate to initiate growth as well as pectinase production (MRUDULA ; ANITHARAJ, 2011; JACOB; PREMA, 2008). The $\mathrm{pH}$ is another significant parameter which plays a crucial role for pectinase production. The $\mathrm{pH}$ regulates and promote the synthesis of extracellular enzyme by microorganism particularly fungi (RAMESH; LONSANE, 1990). In order to determine the optimal $\mathrm{pH}$ for pectinase production by $A$. niger 
ABT-5 different $\mathrm{pH}$ (3-10) were tested. The highest enzyme yield was observed at pH6.0 (Fig 2e). The reason might be the fungi can grow in acidic condition and any change in the $\mathrm{pH}$ of the media produced significant effects on the activity of the enzyme (TURNER, 2010). The higher and lower $\mathrm{pH}$ other than optimal inactivate the enzyme and its
ABDULLAH, R. et al.

production (AMADIOHA, 1993). RAMANUJAM; Subramani (2008) presented similar findings that optimal $\mathrm{pH}$ for pectinase production by A.niger was 6. However, Adeleke et al. (2012) reported pH range between 5-5.5 for optimal pectinase production

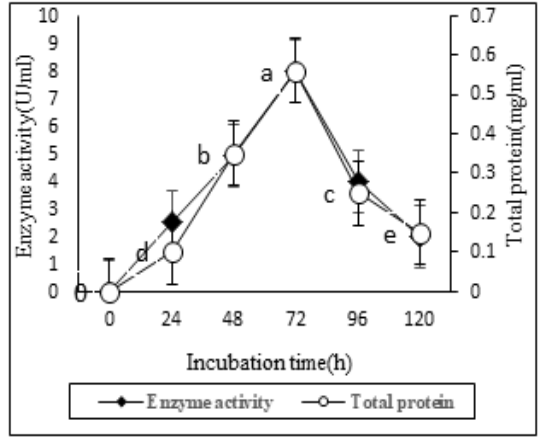

a

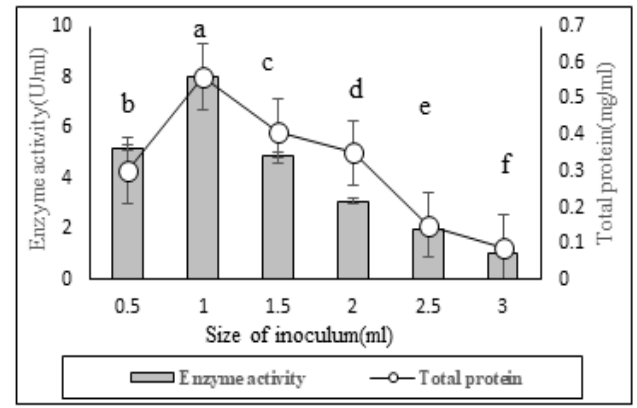

d
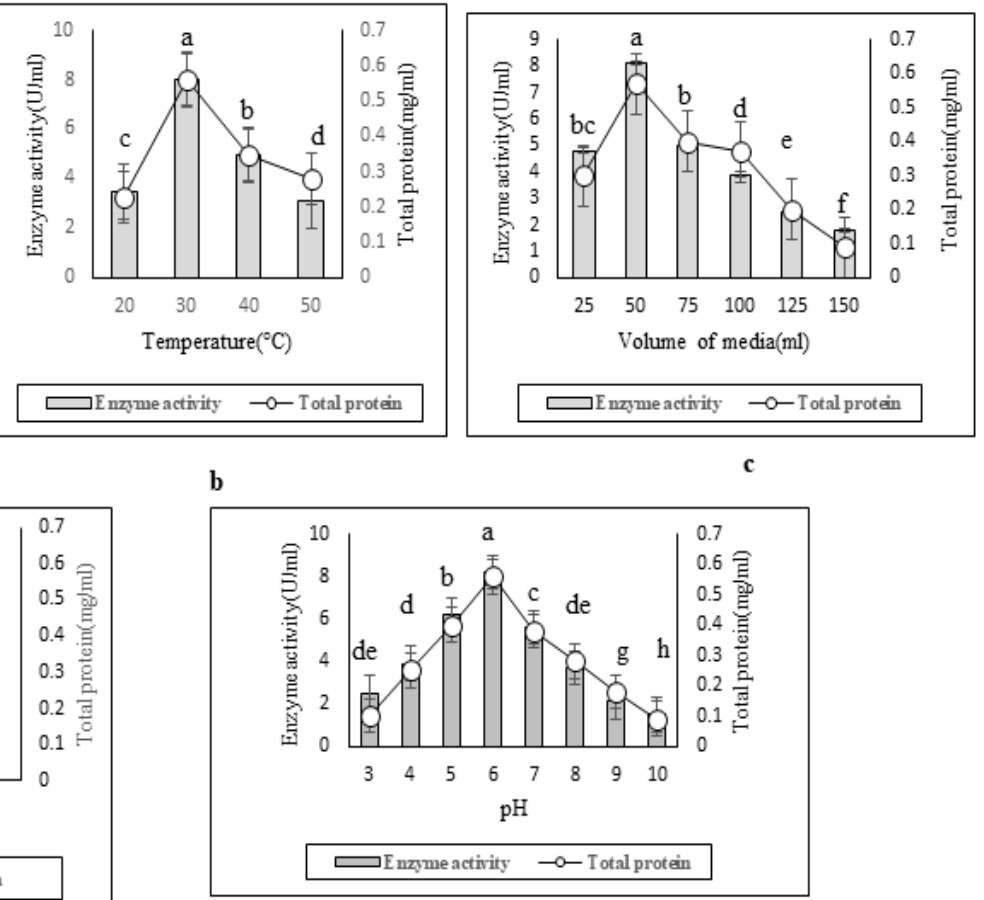

e

Figure 2. Impact of different physicochemical parameter on the production of pectinase (a) incubation time (b) Temperature (c) Volume of media (d) Size of inoculum (e) $\mathrm{pH}$

Each value is mean of triplicates. \pm indicates the standard error from mean value. Duncan multiple range test shows that mean difference is significant at level of $\mathrm{p} \leq 0.05$ represented by different superscripts

Another significant factor is carbon source which plays a significant role in cell metabolism and pectinase synthesis (GAUTAM et al., 2011). In the present study different carbon sources were used such as glucose, sucrose, fructose, starch and lactose etc. Fructose gave the maximal production of pectinase out of all carbon sources used (Fig3a). The reason could be that the fructose is a simple sugar and pectinolytic microorganism utilizes simple sugars more efficiently as compared to complex polysaccharide such as starch and produced maximum, galacturonic acid from their substrates. Similar finding was also reported by Rajmane; Korekar (2012) in Aspergillus. In submerged fermentation the pectinase activity is inhibited by the presence of glucose and other sugars in the medium (SANDHYA; KURUP, 2013).Various concentrations of fructose ranges from $(0.5-3 \%)$ were optimized for pectinase production. The $1.5 \%$ concentration was selected best because it gave the highest pectinase production as compared to other concentration (Fig $3 \mathrm{~b}$ ). Any increase in the concentration of fructose reduces the enzyme production. The reason might be the highest concentration of fructose act as a catabolite repressor (AGUILAR et al., 1991).

The nitrogen sources also effect on the pectinase production. Different organic and inorganic nitrogen sources (yeast extract, peptone, meat extract, urea, ammonium sulphate, sodium nitrate, potassium nitrate, ammonium chloride) were evaluated for pectinase production. Organic nitrogen 
source produced higher yield of pectinase as compared to inorganic sources. This predominance of organic nitrogen sources on inorganic sources might be due to the fact that the organic nitrogen sources were better growth stimulators (SASI et al.,

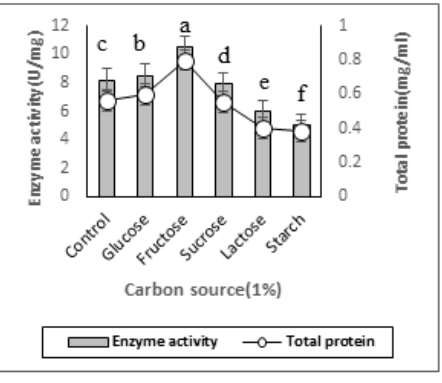

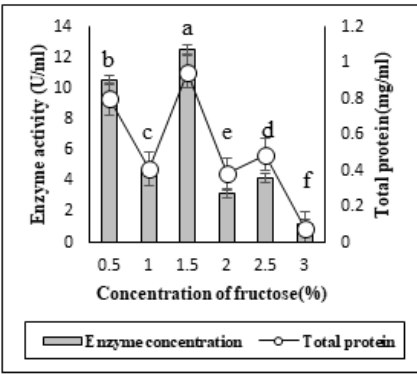

2010). Urea gave the maximum pectinase production (Fig 3c). The reason might be Urea being an organic nitrogen source might contain an accessory growth factor (PADHIAR et al., 2011).

Figure 3. Impact of nutritional factors on the production of pectinase (a) Carbon sources (b) Concentration of fructose (c) Nitrogen sources

Each value is mean of triplicates. \pm indicates the standard error from mean value. Duncan multiple range test shows that mean difference is significant at level of $\mathrm{p} \leq 0.05$ represented by different superscripts

RESUMO: O presente estudo trata da triagem de isolamento e otimização da cepa fúngica para produção de pectinase. As cepas fúngicas foram isoladas de diferentes fontes, incluindo solo, frutas, etc. A triagem qualitativa foi realizada com base na zona de hidrólise da pectina. Enquanto, a triagem quantitativa foi realizada utilizando fermentação submersa. Entre todas as cepas, as cepas que apresentaram maior potencial pectinolítico foram selecionadas e atribuídas ao código Aspergillus niger ABT-5. Avaliou-se a influência de diferentes meios de fermentação na produção de pectinase. $\mathrm{O}$ meio M5 contendo 10g de farelo de trigo, meio nutriente contendo (g / 1) de (NH4)2SO4 6.0, K2HPO4 6.0, KH2PO4 6.0, $\mathrm{MgSO} 4.7 \mathrm{H} 2 \mathrm{O}$ 0.1, proporcionou a maior produção de pectinase. Os outros parâmetros físico-químicos importantes, incluindo período de incubação, temperatura e volume dos meios, tamanho do inóculo, fontes de carbono e nitrogênio também foram otimizados para a produção de pectinase. A maior produção de pectinase $(15,5 \mathrm{U} / \mathrm{ml})$ foi obtida às $72 \mathrm{~h}$ de incubação, $\mathrm{pH} 6$, temperatura $30^{\circ} \mathrm{C}$, volume dos meios $50 \mathrm{ml}$. A frutose e a ureia foram designadas como melhores fontes de carbono e nitrogênio posteriormente.

PALAVRAS-CHAVE: Pectinase. Aspergillus niger. Fermentação submersa. Farelo de trigo.

\section{REFERENCES}

ADELEKE, A. J.; ODUNFA, S. A.; OLANBIWONNINU, A.; OWOSENI, M. C. Production of cellulase and pectinase from orange peels by fungi. Natural Science, v. 10, n. 5, p. 107-112, 2012.

AGUILAR, G.; TREJO, B. A.; GARCÍA, J. M.; HUITRÓN, C. Influence of pH on endo-and exo-pectinase production by Aspergillus sp. CH-Y-1043. Canadian Journal of Microbiology, v. 37, n. 12, p. 912-917, 1991. https://doi.org/10.1139/m91-158

AHMED, I., ZIA, M. A., HUSSAIN, M. A., AKRAM, Z., NAVEED, M. T.; NOWROUZI, A. Bioprocessing of citrus waste peel for induced pectinase production by Aspergillus niger; its purification and characterization. Journal of Radiation Research and Applied Sciences, v. 9, n. 2, p. 148-154, 2016. https://doi.org/10.1016/j.jrras.2015.11.003

ANITHA, T. S.; PALANIVELU, P. Purification and characterization of an extracellular keratinolytic protease from a new isolate of Aspergillus parasiticus. Protein Expression and Purification, v. 88, n. 2, p. 214-220, 2013. https://doi.org/10.1016/j.pep.2013.01.007

BAILEY, M. J.; PESSA, E. Strain and process for production of polygalacturonase. Enzyme and Microbial Technology, v. 12 , n. 4, p. 266-271, 1990. https://doi.org/10.1016/0141-0229(90)90098-B 
BALKAN, B.; ERTAN, F. Production of $\alpha$-amylase from Penicillium chrysogenum under solid-state fermentation by Using Some Agricultural By-Products. Food Technology and Biotechnology, v. 45, n. 4, p. 439-432, 2007.

BENNAMOUN, L.; HILIGSMANN, S.; DAKHMOUCHE, S.; AIT-KAKI, A.; LABBANI, F.-Z. K.; NOUADRI, T.; MERAIHI, Z.; TURCHETTI, B.; BUZZINI, P.; THONART, P. Production and Properties of a Thermostable, $\mathrm{pH}$-Stable Exo-Polygalacturonase Using Aureobasidium pullulans Isolated from Saharan Soil of Algeria Grown on Tomato Pomace. Foods, v. 5 n. 4, p. 72, 2016. https://doi.org/10.3390/foods5040072

BRADFORD, M. M. A rapid and sensitive method for the quantitation of microgram quantities of protein utilizing the principle of protein dye binding. Analytical Biochemistry, v. 72 n. 2,p. 248-254, 1976. https://doi.org/10.1016/0003-2697(76)90527-3

GAUTAM, S.; BUNDELA, P.; PANDEY, A.; KHAN, J.; AWASTHI, M.; SARSAIYA, S; Optimization for the production of cellulase enzyme from municipal solid waste residue by two novel cellulolytic fungi.

Biotechnology Research International, v. 2011, n. 25 , p. 1-8, 2011. https://doi.org/10.4061/2011/810425

HANNAN, A.; BAJWA, R.; LATIF, Z. Status of Aspergillus niger strains for pectinases production potential. Pakistan Journal of Phytopathology, v. 21, n. 1, p. 77-82, 2009.

HAQ, I.; MUKHTAR, H.; UMBER, N. Fermentation medium optimization for the biosynthesis of protease by Penicillium chrysogenum in shake flasks. Pakistan Journal of Zoology, v. 40 n. 2, p. 69-73, 2008.

JACOB, N.; PREMA, P. Novel process for the simultaneous extraction and degumming of banana fibers under solidstate cultivation. Brazilian Journal of Microbiology, v. 39, n. 1, 115-121, 2008. https://doi.org/10.1590/S1517-83822008000100025

KUNTE, S.; SHASTRI, N; 1980. Studies on extracellular production of pectolytic enzymes by a strain of Alternaria alternata. Indian Journal of Microbiology, v. 20, n. 3, p. 211-215.

MALDONADO, M.; STRASSER DE SAAD, A. Production of pectinesterase and polygalacturonase by Aspergillus niger in submerged and solid state systems. Journal of Industrial Microbiology and Biotechnology, v. 20 n.1, p.34-38, 1998. https://doi.org/10.1038/sj.jim.2900470

MATHEW, J. J.; VAZHACHARICKAL, P. J.; SAJESHKUMAR, N.; ASHOKAN, A. Amylase production by Aspergillus niger through submerged fermentation using starchy food byproducts as substrate. International Journal of Herbal Medicine, v.4, n.6, p. 34-40., 2016.

MILLER, G. L. Use of dinitrosalicylic acid reagent for determination of reducing sugar. . Analytical Chemistry, v.31, n. 3, p. 426-428, 1959. https://doi.org/10.1021/ac60147a030

MINJARES-CARRANCO, A.; TREJO-AGUILAR, B. A.; AGUILAR, G.; VINIEGRA-GONZÁLEZ, G. Physiological comparison between pectinase-producing mutants of Aspergillus niger adapted either to solidstate fermentation or submerged fermentation. Enzyme and Microbial Technology, v. 21, n. 1, p. 25-31. 1997. https://doi.org/10.1016/S0141-0229(96)00212-8

MOREIRA, F. G.; REIS, S. D.; COSTA, M. A. F.; SOUZA, C. G. M. D.; PERALTA, R. M. Production of hydrolytic enzymes by the plant pathogenic fungus Myrothecium verrucaria in submerged cultures. Brazilian Journal of Microbiology, v. 36 , n. 1, p. 7-11. 2005. https://doi.org/10.1590/S1517-83822005000100002

MRUDULA, S.; ANITHARAJ, R. Pectinase production in solid state fermentation by Aspergillus niger using orange peel as substrate. Global Journal of Biotechnology and Biochemistry Research, v. 6, n. 2; p. 64-71, 2011.

NEETA, R., ANUPAMA, S., ANJUVAN, S. AND GIRIDHAR, S. Production of polygalacturonase and pectin methyl esterase from agrowaste by using various isolation of Aspergillus niger. Insight Microbiology, v. 1, $\mathrm{n}$. 1, p. 1-7, 2011. https://doi.org/10.5567/IMICRO-IK.2011.1.7 
OKAFOR, U.; OKOCHI, V.; CHINEDU, S. ; EBUEHI, O.; ONYGEME-OKERENTA, B. Pectinolytic activity of wild-type filamentous fungi fermented on agro-wastes. African Journal of Microbiology Research, v. 4, n. 24, p. 2729-2734, 2010

PADHIAR, I., DAS, A. AND BHATTACHARYA, S.. Candida albicans and Aspergillus flavus. Pakistan Journal of Biological Sciences, v. 14, n. 22, p. 1011-1018, 2011

PALANIYAPPAN, M.; VIJAYAGOPAL, V.; VISWANATHAN, R.; VIRUTHAGIRI, T. Screening of natural substrates and optimization of operating variables on the production of pectinase by submerged fermentation using Aspergillus niger MTCC 281. African Journal of Biotechnology, v. 8, n.4, .p. 682-686, 2009.

PINHEIRO, V. E.; DESAGIACOMO, C. C. V.; MICHELIN, M.; MALLER, A.; MONTEIRO, L. M. O.; JORGE, J. A.; POLIZELI, M. D. L. T. D. Neosartorya glabra polygalacturonase produced from fruit peels as inducers has the potential for application in passion fruit and apple juices. Brazilian Journal of Food Technology, v. 20,n. e2016163, 2017. https://doi.org/10.1590/1981-6723.16316

RAJMANE, S. D.; KOREKAR, S. L. Impact of carbon and nitrogen sources on pectinase production of postharvest fungi. Current Botany, v 3, n.3, p. 1-3, 2012.

RAMANUJAM, N.; SUBRAMANI, S. P. Production of pectin lyase by solid-state fermentation of sugarcane bagasse using Aspergillus niger. Advance Biotechnology. v. 3, n. 3, p. 30-33, 2008.

RAMESH, M.; LONSANE, B; Characteristics and Novel Features of Thermostable $\alpha$-Amylase Produced by Bacillus licheniformis M27 under Solid State Fermentation. Starch-Stärke, v. 42, n. 6, p. 233-238, 1990. https://doi.org/10.1002/star.19900420608

REID, I.; RICARD, M. Pectinase in papermaking: solving retention problems in mechanical pulps bleached with hydrogen peroxide. Enzyme and Microbial Technology, v. 26, n. 2, p. 115-123, 2000. https://doi.org/10.1016/S0141-0229(99)00131-3

SANDHYA, R.; KURUP, G. Screening and isolation of pectinase from fruit and vegetable wastes and the use of orange waste as a substrate for pectinase production. International Research Journal Biololgical Science, v. 2 n. 9, p. 34-39, 2013.

SASI, A.; KANI, M.; PANNEERSELVAM, A.; JEGADEESH, G.; MUTHU, K. KUMAR, M. R. Optimizing the conditions of $\alpha$-amylase by an Esturian strain of Aspergillus spp. African Journal of Microbiology Research, v. 4, n. 8, p. 581-586, 2010.

SETHI, B.K.; PANDA, B.; SAHOO, S.L. Biosynthesis of industrially relevant extracellular pectinase from Aspergillus terreus NCFT 4269.10 using orange peels as substrate. Asian Journal of Biotechology, v. 7, n. 1, p. 13-22, 2015. https://doi.org/10.3923/ajbkr.2015.13.22

SOARES, M. M.; SILVA, R. D.; GOMES, E. Screening of bacterial strains for pectinolytic activity: characterization of the polygalacturonase produced by Bacillus sp. Revista de Microbiologia, v. 30 n. 4; p. 299-303, 1999. https://doi.org/10.1590/S0001-37141999000400002

THANGARATHAM, T.; MANIMEGALAI, G. Optimization and production of pectinase using agro waste by solid state and submerged fermentation. Intrnational Journal of Current Microbiology and Applied Sciences, v. 3, n. 9, p. 357-365, 2014.

TURNER, B. L. Variation in pH optima of hydrolytic enzyme activities in tropical rain forest soils. Applied and Environmental Microbiology, v. 76, n. 19, p. 6485-6493, 2010. https://doi.org/10.1128/AEM.00560-10 